\title{
Alternaria dauci causes leaf spots and leaf blight of coriander (Coriandrum sativum) in Brazil
}

\author{
Paloma S. Mansur ${ }^{1} \cdot$ André L. Silva $^{1} \cdot$ Sara S. Salcedo ${ }^{1} \cdot$ Robert W. Barreto $^{1} \cdot$ Adans A. Colmán $^{1,2}$ (D) \\ Received: 18 November 2019 / Accepted: 8 October 2020 / Published online: 19 October 2020 \\ (C) Australasian Plant Pathology Society Inc. 2020
}

\begin{abstract}
Alternaria dauci is fully confirmed to cause leaf spots and leaf blight of coriander (Coriandrum sativum) in Brazil based on observations made of blighted plants at a demonstration plot (Infectarium) at Viçosa (state of Minas Gerais) Brazil. Identification was supported by a combination of morphological, cultural and molecular features. A representative herbarium sample and an isolate were deposited in public collections as well as DNA sequences. Pathogenicity tests were conducted and Koch's postulates were fulfilled.
\end{abstract}

Keywords Etiology $\cdot$ Phylogeny $\cdot$ Section Porri $\cdot$ Pathogenicity $\cdot$ Pleosporaceae

Coriander (Coriandrum sativum), also known as cilantro (coentro in Brazil) is an annual herb of the Apiaceae. It is widely cultivated and used as a condiment herb worldwide (Simpson and Connor-Ogorzaly 2001) and also in Brazil. Several fungal pathogens have been reported as causing leaf spots on coriander in Brazil (Farr and Rossman 2019) and Alternaria leaf spot is considered an important disease of coriander in Brazil (Reis and Lopes 2016).

In July 2018, all plants growing in a demonstration plot in the Infectarium - the plant disease garden - of the Departamento de Fitopatologia of the Universidade

Adans A. Colmán

adan-colman@hotmail.com

Paloma S. Mansur

paloma.mansur@ufv.br

André L. Silva

als9528@gmail.com

Sara S. Salcedo

taphrina10@gmail.com

Robert W. Barreto

rbarreto@ufv.br

1 Departamento de Fitopatologia, Universidade Federal de Viçosa, Viçosa, Minas Gerais 36570-900, Brazil

2 Present address: Facultad de Ciencias Agrarias, Universidad Nacional de Asunción, San Lorenzo, Paraguay
Federal de Viçosa (municipality of Viçosa, state of Minas Gerais, Brazil) were found to be attacked by a disease leading to severe leaf blight symptoms. Firstly small round to oval, 3-5 $\mathrm{mm}$ diam., leaf spot appeared which quickly coalesced and turned into necrotic blight of entire leaves. Samples were collected and examined under a dissecting microscope and a dematiaceous fungus was found to be regularly associated with the necrotic tissues. Under a dissecting microscope (Olympus SZX7) conidia were taken from infected leaves with a sterile fine pointed needle and transferred onto previously marked positions of V8 juice-agar plates. Each position of those plates was then examined, under the high power of the dissecting microscope, to select positions where single conidia were deposited. Those points of the plates were further marked, at the underside of the plates, indicating that colonies from these positions represented single-spore isolates. After 1 week of growth in the incubator, at $25^{\circ} \mathrm{C}$, a fragment of the margin of one selected single spore colony was taken and transferred to a tube containing potato carrot-agar. This representative culture was deposited in the culture collection of the Universidade Federal de Viçosa (Acc No COAD 2594) and used in this study. Additionally, a representative specimen of diseased coriander was dried in a plant press and deposited in the local herbarium (Acc. No VIC 47142).

Slides were prepared by scraping fungal structures from sporulating colonies on leaves and mounting these on a drop 
of lactophenol. Observations were made under a microscope (Olympus BX 53) equipped with differential interference contrast (DIC) illumination and connected to an Olympus Q-color $5^{\mathrm{TM}}$ camera. The fungus on coriander had the following morphology: conidiophores forming loose groups, subcylindrical, straight to somewhat sinuose, $27.5-75 \times 5-10 \mu \mathrm{m}, 1-4$ septate, pale brown to brown, smooth; conidiogenous cells subcylindrical, geniculate, (7.5) $15-27.5 \quad(37.5) \times 5-10 \mu \mathrm{m}$, conidiogenous loci terminal to intercalary $2.5-7.5 \mu \mathrm{m}$ diam.; conidia solitary, (125) 200-300 (340) $\times 17.5-$ $22 \mu \mathrm{m}, 1-8$ longitudinally and $8-15$ transversally septae, beak up up $280 \mu \mathrm{m}$ long, pale brown, walls somewhat verruculose (Fig. 1).

DNA was extracted from mycelium of COAD 2594 grown in $20 \mathrm{ml}$ of potato dextrose broth at $23 \pm 2{ }^{\circ} \mathrm{C}$ for 4 days. Extraction was performed with a Wizard Genomic DNA Purification Kit (Promega) according to the manufacturer's recommendations. The glyceraldehyde 3-phosphate dehydrogenase (GAPDH) region was amplified with the primers gpd1 and gpd2 (Berbee et al. 1999), the RPB2 region with RPB2$5 F 2$ (Sung et al. 2007) and fRPB2-7cR (Liu et al. 1999) and the Alt a1 region with the primers Alt-for and Alt-rev (Hong et al. 2005). PCR was performed following the procedure described in Colmán et al. (2018) and phylogenetic analyses were performed as described in Woudenberg et al. (2013). Bayesian inference analyses were performed with the CIPRES web portal using MrBayes v. 3.2.6. (Miller et al. 2015). The jmodeltest (Darriba et al. 2012) was used for estimation of sequence evolution. Based on the phylogenetic analyses results combined GAPDH, Alt 1 and RPB2 gene regions, our isolate COAD 2594 was identified as belonging to Alternaria dauci (Fig. 2). Sequences obtained in this work were deposited in GenBank (Table 1).

To confirm the pathogenicity of COAD 2594, 4 month old healthy coriander plants were inoculated. Additionally, groups of four pots (one healthy plant per pot) containing either carrot, celery or parsley were also inoculated with COAD 2594. A conidial suspension was prepared by flooding sporulating 7-day-old cultures formed on V8 juice-agar plates with sterile distilled water (SDA) and scraping their surface with a rubber spatula. A haemocytometer was used to calculate the concentration of spores $/ \mathrm{ml}$ which was then adjusted to $10^{6}$ conidia/ml. Plants were sprayed until runoff and covered with a plastic bag for $48 \mathrm{~h}$ to keep humidity levels high. One healthy plant of each species treated similarly but sprayed with SDA only served as controls. Typical symptoms of disease were observed 2-4 days after inoculation. Control plants remained healthy. Alternaria

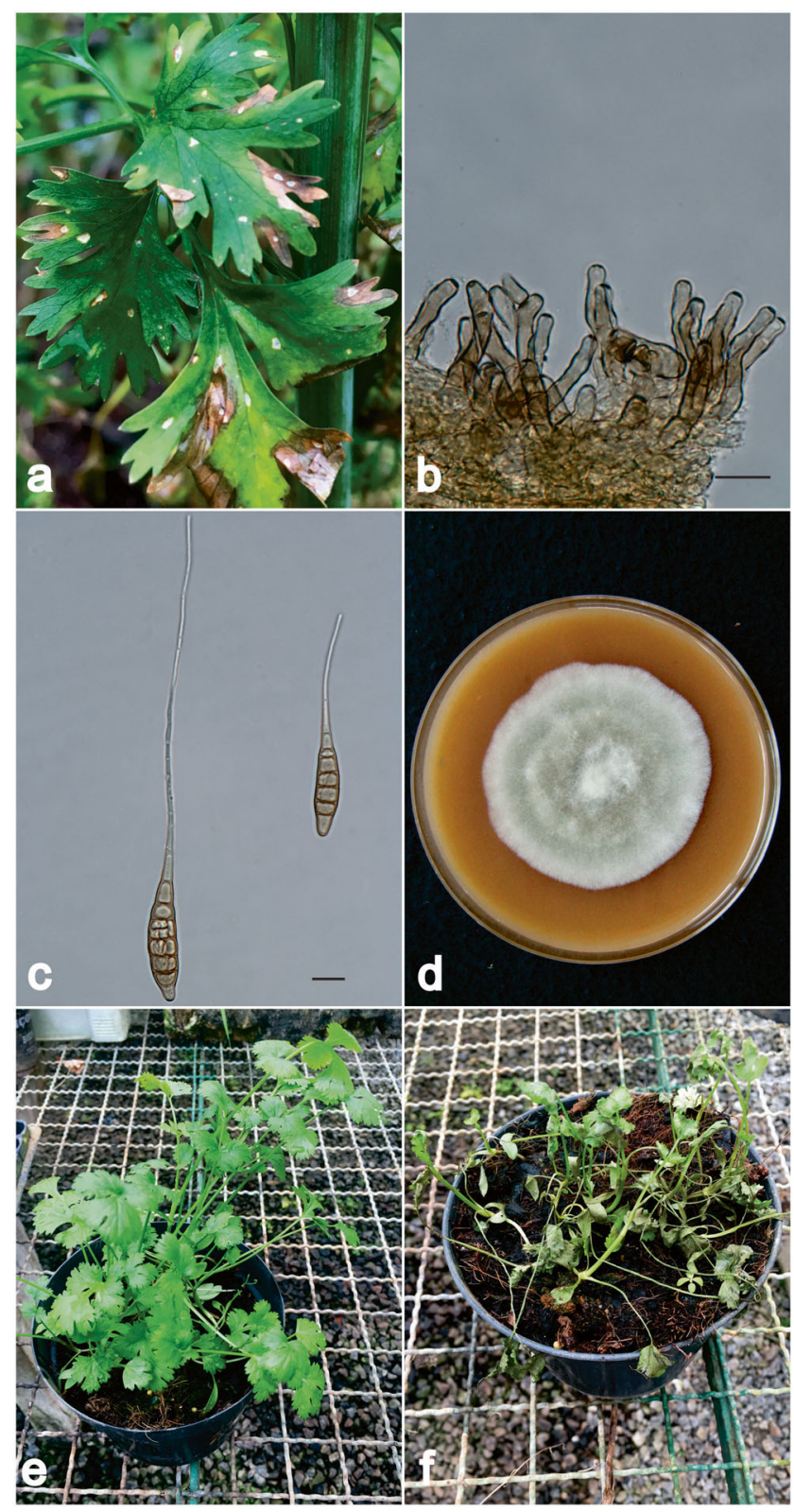

Fig. 1 Alternaria dauci on coriander (Coriandrum sativum). a Leaf spot and some blight symptoms on coriander; $\mathbf{b}$ Group of conidiophores of A. dauci; $\mathbf{c}$ Conidia with long septate beaks, $\mathbf{d}$ Colony of A. dauci on V8 juice-agar; e-f Pathogenicity test on coriander plants, control (e) and inoculated plants (f) 4 days after inoculation. Scale bars $20 \mu \mathrm{m}$

dauci sporulated abundantly on necrotic tissues and was reisolated on V8 juice-agar plates producing sporulating cultures. The morphology of the fungus reisolated from necrotic tissues of inoculated plants was examined under the microscope and found to have a morphology identical to COAD 2594 fulfilling Koch's postulates.

Several species of Alternaria have been reported on C. sativum (Farr and Rossman 2019). Of these (A. poonensis) was originally described by Raghunath 
Table 1 GenBank accession number of sequences obtained in this study and other Alternaria spp. used for phylogenetic analysis

\begin{tabular}{|c|c|c|c|c|c|c|}
\hline \multirow[t]{2}{*}{ Species Name } & \multirow[t]{2}{*}{ Host } & \multirow[t]{2}{*}{ Strain number } & \multirow[t]{2}{*}{ Country } & \multicolumn{3}{|c|}{ GenBank accession number } \\
\hline & & & & Alt 1 & GPDH & RPB2 \\
\hline Alternaria anagallidis & Anagallis arvensis & CBS 117128 & New Zealand & KJ718628 & KJ717961 & KJ718282 \\
\hline Alternaria anagallidis & Anagallis arvensis & CBS 117129 & New Zealand & KJ718629 & KJ717962 & KJ718283 \\
\hline Alternaria argyroxiphii & Argyroxiphium sp & CBS 117122 & USA & KJ71863 & JQ646350 & KJ718286 \\
\hline Alternaria argyroxiphii & Ipomoea batatas & PPRI 11848 & South Africa & KJ718633 & KJ717965 & KJ718287 \\
\hline Alternaria argyroxiphii & Ipomoea batatas & PPRI 11971 & South Africa & KJ718634 & KJ717966 & KJ718288 \\
\hline Alternaria bataticola & Ipomoea batatas & CBS 531.63 & Japan & JQ646433 & JQ646349 & KJ718291 \\
\hline Alternaria bataticola & Ipomoea batatas & CBS 532.63 & Japan & KJ718637 & KJ717969 & KJ718292 \\
\hline Alternaria bataticola & Ipomoea batatas & CBS 117095 & Australia & KJ718638 & KJ717970 & KJ718293 \\
\hline Alternaria bataticola & Ipomoea batatas & CBS 117096 & Australia & KJ718639 & KJ717971 & KJ718294 \\
\hline Alternaria dauci & Daucus carota & CBS 111.38 & Italy & KJ718673 & KJ718005 & KJ718331 \\
\hline Alternaria dauci & Daucus carota & CBS 345.79 & New Zealand & KJ718675 & KJ718007 & KJ718333 \\
\hline A. dauci (syn. A. poonensis) & Coriadrum sativum & CBS 117.100 & Puerto Rico & KJ718680 & JQ646348 & KJ718338 \\
\hline Alternaria dauci & Coriadrum sativum & USFL-3 & USA & MF595071 & MF595072 & - \\
\hline Alternaria dauci & Coriadrum sativum & NB625 & Algeria & - & MK513412 & MK513423 \\
\hline Alternaria dauci & Coriadrum sativum & NB622 & Algeria & - & MK513409 & MK513420 \\
\hline Alternaria dauci & Coriadrum sativum & COAD 2594 & Brazil & MN433697 & MT050451 & MN433698 \\
\hline Alternaria echinaceae & Echinaceae sp. & CBS 116117 & New Zealand & KJ718684 & KJ718015 & KJ718343 \\
\hline Alternaria echinaceae & Echinaceae sp. & CBS116118 & New Zealand & KJ718685 & KJ718016 & KJ718344 \\
\hline Alternaria euphorbiicola & Euphorbia hyssopifolia & CBS 133874 & USA & KJ718019 & KJ718687 & KJ718347 \\
\hline Alternaria euphorbiicola & Euphorbia pulcherrima & CBS 19886 & USA & KJ718017 & KJ718686 & KJ718345 \\
\hline Alternaria ipomeae & Ipomoea batatas & CBS 219.79 & Ethiopia & KJ718689 & KJ718020 & KJ718348 \\
\hline Alternaria ipomeae & Ipomoea batatas & PPRI 8988 & South Africa & KJ718690 & KJ718021 & KJ718349 \\
\hline Alternaria neoipomeae & Ipomoea batatas & PPRI 8990 & South Africa & KJ718706 & KJ718035 & KJ718370 \\
\hline Alternaria neoipomeae & Ipomoea batatas & PPRI 13903 & South Africa & KJ718709 & KJ718038 & KJ718373 \\
\hline Alternaria tagetica & Tagetes sp. & CBS 297.79 & UK & KJ718759 & KJ718080 & KJ718428 \\
\hline Alternaria tagetica & Tagetes sp. & CBS 298.79 & UK & KJ718760 & KJ718081 & KJ718429 \\
\hline Alternaria tagetica & Tagetes erecta & CBS 479.81 & UK & KJ718761 & KC584143 & KC584434 \\
\hline Alternaria tropica & Passiflora edulis & CBS 631.93 & USA & KJ718768 & KJ718088 & KJ718436 \\
\hline Alternaria tropica & Passiflora edulis & CBS 117216 & USA & KJ718769 & KJ718089 & KJ718437 \\
\hline
\end{tabular}

(1963) based on a sample of diseased coriander from India. This was based on morphological features and supposed host-specificity. Morphology of COAD 2594 was found to be rather similar to that described by Raghunath (1963) for A. poonensis, including for the absence of bifurcated beaks, thought to be typical for A. dauci but not seen in COAD 2594 (either from in planta or in vitro materials). Nevertheless, based on their molecular phylogenetic analysis Woudenberg et al. (2014), placed A. poonensis as a synonym of A. dauci. Results of our phylogenetic analysis of COAD 2594 were in agreement with Woudenberg et al. (2014) (Fig. 2). COAD 2594 grouped with the type strain of A. dauci (CBS 111.38) and other A. dauci strains isolated from coriander in the United
States US-FL-1 (Poudel and Zhang 2018) and Algeria NB622 (Bessadat et al. 2019). Alternaria dauci is now recognized to be a polyphagous pathogen infecting several plants in the Apiaceae. COAD 2594 was also proven to be capable of infecting carrots, parsley and celery in our inoculation studies, further confirming the polyphagous status (within the Apiaceae) of A. dauci. In Brazil this species has already been reported in association with coriander seeds and plants (Reis et al. 2006). Nevertheless these reports were never supported by molecular data and no voucher specimens were deposited in herbaria or culture collections. Here the identity of Alternaria dauci as the ethiological agent of leaf spots and blight of coriander in Brazil is fully confirmed for the first time. 
Fig. 2 Multilocus phylogenetic tree of Alternaria species inferred from Bayesian analysis based on combined Alt a 1, GAPDH and RPB2 sequences. Bayesian posterior probabilities above 0.7 are indicated above the nodes. Isolate from Brazil are highlighted in bold. The tree was rooted with Alternaria euphorbiicola (CBS 133874 and CBS 198.86) isolates

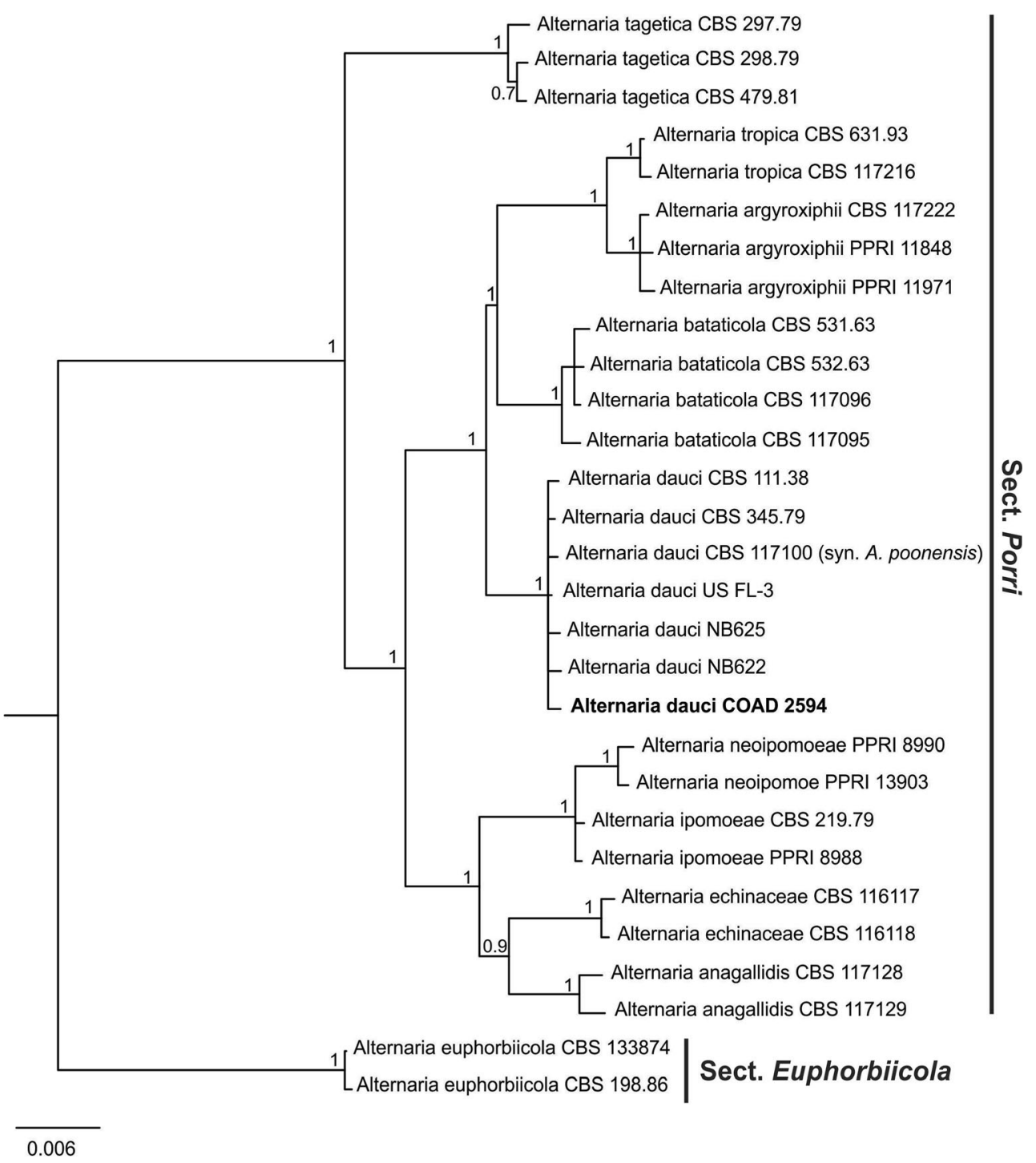

\section{References}

Berbee ML, Pirseyedi M, Hubbard S (1999) Cochliobolus phylogenetics and the origin of known, highly virulent pathogens, inferred from ITS and glyceraldehyde-3-phosphate dehydrogenase gene sequences. Mycologia 91:964-977

Bessadat N, Hamon B, Bataillé-Simoneau N, Mabrouk K, Simoneau P (2019) First report of Alternaria dauci causing leaf blight of coriander (Coriandrum sativum) in Algeria. Plant Dis 103:2471. https:// doi.org/10.1094/PDIS-03-19-0582-PDN

Colmán A, Freitas L, Barreto RW (2018) First report of Seimatosporium hypericinum causing leaf spots on the ornamental shrub Hypericum $\times$ inodorum and in Brazil. Aust Plant Dis Notes 13:38

Darriba D, Taboada GL, Doallo R, Posada D (2012) jModelTest 2: more models, new heuristics and parallel computing. Nat Methods 9:772

Farr DF, Rossman AY (2019) Fungal database, U. S. National Fungus Colletions, ARS, USDA. https://nt.ars-grin.gov/fungaldatabases/. Accessed 11 June 2019

Hong SG, Cramer RA, Lawrence CB, Pryor BM (2005) Alt a 1 allergen homologs from Alternaria and related taxa: analysis of phylogenetic content and secondary structure. Fungal Genet Biol 42:119-129
Liu YJ, Whelen S, Hall BD (1999) Phylogenetic relationships among ascomycetes: evidence from an RNA polymerse II subunit. Mol Biol Evol 16:1799-1808

Miller MA, Schwartz T, Pickett BE, He S, Klem EB, Scheuermann RH, Passarotti M, Kaufman S, O'Leary MA (2015) A RESTful API for access to phylogenetic tools via the CIPRES science gateway. Evol Bioinforma 11:43-48. https://doi.org/10.4137/EBO.S21501

Poudel B, Zhang S (2018) First report of Alternaria leaf spot of cilantro (Coriandrum sativum) caused by Alternaria dauci in the United States. Plant Dis. 102: https://doi.org/10.1094/PDIS-08-17-1297PDN

Raghunath T (1963) A new species of Alternaria causing blight of Coriandrum sativum L. Mycopathologia 21:315-317

Reis A, Satelis JF, Pereira RS, Nascimento WM (2006) Associação de Alternaria dauci e A. alternata com sementes de coentro e eficiência do tratamento químico. Hortic Bras 24:107-111

Reis A, Lopes CA (2016) Doenças do coentro no Brasil. Brasília, DF: Embrapa (Embrapa Hortaliças) Circular Técnica, 157:1-6 https:// ainfocnptiaembrapabr/digital/bitstream/item/157359/1/CT-157pdf Acessed 10 May 2019

Simpson BB, Connor-Ogorzaly M (eds) (2001) Economic botany: plants in our world. McGraw-Hill, New York 
Sung GH, Sung JM, Hywel-Jones NL, Spatafora JW (2007) A multi-gene phylogeny of Clavicipitaceae (Ascomycota, fungi): identification of localized incongruence using a combinational bootstrap approach. Mol Phylogenet Evol 44:12041223
Woudenberg JHC, Groenewald JZ, Binder M, Crous PW (2013) Alternaria redefined. Stud Mycol 75:171-212

Woudenberg JHC, Truter M, Groenewald JZ, Crous PW (2014) Largespored Alternaria pathogens in section Porri disentangled. Stud Mycol 79:1-49 